\title{
Effect of a Field-Source Mixture of Citrus Viroids on the Performance of 'Nules' Clementine and 'Navelina' Sweet Orange Trees Grafted on Carrizo Citrange
}

\author{
S. M. Bani Hashemian, P. Serra, C. J. Barbosa, J. Juárez, P. Aleza, J. M. Corvera, and A. Lluch, Departamento \\ de Protección Vegetal y Biotecnología, Instituto Valenciano de Investigaciones Agrarias, Apartado Oficial, 46113- \\ Moncada, Valencia, Spain; J. A. Pina, Servicio de Inspección Fitosanitaria, Valencia, Spain; and N. Duran-Vila, \\ Departamento de Protección Vegetal y Biotecnología, Instituto Valenciano de Investigationes Agrarias, Apartado \\ Oficial, 46113-Moncada, Valencia, Spain
}

\begin{abstract}
Bani Hashemian, S. M., Serra, P., Barbosa, C. J., Juárez, J., Aleza, P., Corvera, J. M., Lluch, A., Pina, J. A., and Duran-Vila, N. 2009. Effect of a field-source mixture of citrus viroids on the performance of 'Nules' clementine and 'Navelina' sweet orange trees grafted on Carrizo citrange. Plant Dis. 93:699-707.

A field-source mixture of citrus viroids was characterized and shown to contain Citrus exocortis viroid (CEVd), Hop stunt viroid (HSVd), Citrus bent leaf viroid (CBLVd), and Citrus dwarfing viroid (CDVd). Sequencing results showed that: (i) CEVd contained the $P_{L}$ and $P_{R}$ characteristic of class A variants; (ii) HSVd was a noncachexia variant; (iii) CBLVd was related to CVd-Ia variants; (iv) CDVd was a mixture of two types (CVd-IIIa and CVd-IIIb) of variants. The presence of the same type of variants in inoculated clementine (Citrus clementina 'Nules') and sweet orange (C. sinensis 'Navelina') trees on Carrizo citrange (Poncirus trifoliata $\times$ C. sinensis) rootstocks was confirmed. The effect of infection was determined by assessing the performance of infected and noninfected trees growing in the field. Infection resulted in small trees with reduced canopy, yielding a reduced crop. Fruit characteristics were also affected: (i) clementine and sweet orange fruits from infected trees were larger than those from noninfected trees; (ii) clementine fruits from infected trees differed in shape from those of noninfected trees; (iii) sweet orange fruits from infected trees had maturity indexes and juice contents higher than those from noninfected trees; (iv) in both species, the density of the juice, the amount of soluble solids, and the acidity of the fruits from infected trees were lower than those of fruits from noninfected trees. Infected trees had a poorly developed root system with fibrous roots containing fewer amyloplasts than noninfected trees. The results of an in vitro assay on the induction and development of roots in cultured explants are discussed.
\end{abstract}

Viroids are unencapsidated, small, single-stranded, circular RNAs that replicate autonomously when inoculated into their plant hosts, where they may elicit diseases. Citrus species are natural hosts of several viroids, all of which are in the family Pospiviroidae and are characterized by the presence of a central conserved region (CCR) and the absence of RNA selfcleavage mediated by hammerhead ribozymes (18). In citrus, two viroidinduced diseases, exocortis and cachexia, were described $(7,17)$ before viroids were identified as plant pathogens $(10,42)$. In addition to Citrus exocortis viroid (CEVd) and Hop stunt viroid (HSVd), the respective agents of exocortis and cachexia, additional citrus viroids have been described

Corresponding author: Núria Duran-Vila E-mail: nduran@ivia.es

Current address of C. J. Barbosa: EmbrapaMandioca e Fruticultura, Rua Embrapa, CP. 007, CEP : 44380-000, Cruz das Almas, Bahia, Brasil.

Accepted for publication 20 March 2009.

doi:10.1094/PDIS-93-7-0699

(c) 2009 The American Phytopathological Society
$(11,14,23,43)$. Three of them, Citrus bent leaf viroid (CBLVd), Citrus dwarfing viroid (CDVd) (former Citrus viroid III [CVd-III]), and Citrus bark cracking viroid (CBCVd) (former Citrus viroid IV [CVdIV]), have been included as distinct species in the virus taxonomy scheme established by the International Committee on Taxonomy of Viruses (ICTV) (18). Even though these viroids were initially erroneously considered to be associated with the exocortis syndrome (11), recent studies have elucidated their effect on field-grown trees grafted on viroid-sensitive rootstocks $(41,45,47)$.

Except for countries in which sanitation programs have been implemented, viroids are widespread in commercial citrus plantations, where they are perpetuated with the propagation of infected, symptomless budwood. Usually field trees are coinfected with several viroids, a situation that for many years impaired the understanding of the effect of single or multiple infections on the performance of the host. When several viroids coinfect a single plant, the effects of some may be masked by others, resulting in either attenuation or enhancement of the expected symptoms. Attenuation or "cross protection" is observed when two strains of the same viroid or two closely related viroids coinfect the same plant. This phenomenon has been documented to occur between strains of HSVd (40), between strains of CEVd (16), and between CEVd and CBCVd, two viroids that share sequence homology (46). On the contrary, when unrelated viroid pairs such as CEVd and CDVd, CBLVd and CDVd, CVd-V and CBLVd, and CVd-V and CDVd coinfect the same plant, the symptoms may be much more severe than expected if the effect of the symptoms induced by each viroid were only additive $(43,46)$. This phenomenon, initially described on the Etrog citron (Citrus medica L.) indicator plant $(13,39,43)$, also has been shown to occur in field-grown trees (46).

A field trial was initiated in 1988 to determine the response of clementine $(C$. clementina Hort. ex Tan.) and sweet orange (C. sinensis L.) trees grafted on Carrizo citrange (Poncirus trifoliata $\times C$. sinensis) to infection with a field source of citrus viroid(s). Here we report: (i) the characterization of the viroids present in the source; (ii) the performance of the experimentally infected trees; and (iii) the morphological traits associated with symptom expression.

\section{MATERIALS AND METHODS}

Viroid source. The original source of citrus viroid(s) used in this study was a 'Nules' clementine field tree. This inoculum has been maintained in 'Washington navel' sweet orange as part of the "virus" collection of the Instituto Valenciano de Investigaciones Agrarias (IVIA). Biological indexing was positive on Etrog citron 861-S1 (5,35), which developed severe stunting and leaf epinasty, and negative on Parson's special mandarin, the indicator for cachexia (34).

Plant materials and inoculation. Certified budwood of Nules clementine and 'Navelina' sweet orange that tested negative for graft transmissible diseases was grafted onto Carrizo citrange seedling rootstocks. One year later, a set of 18 trees of each species was graft-inoculated on the scion with the viroid source. Another set of 18 trees of each species was kept as noninoculated controls. Three months after inoculation, the trees of both species were 
planted in a randomized block arrangement, each block consisting of two trees (one inoculated and one noninoculated control), in a calcareous, alkaline $(\mathrm{pH}$ around 8.0), sandy-loam soil suitable for Carrizo citrange. The field plot was located at the Instituto Valenciano de Investigaciones Agrarias, Moncada (Valencia, Spain), and the trees were subjected to the standard pruning and harvesting operations of the region. In order to shape the canopies of the trees, two major prunings were performed during two consecutive years after planting, and suckers were removed in all subsequent years. Tools were disinfested with a sodium hypochlorite solution between trees. All trees were indexed for viroid content 10 years after planting.

Viroid indexing. Biological indexing was performed by graft inoculation on the sensitive 861-S1 selection of Etrog citron grafted on rough lemon (C. jambhiri Lush.) rootstock $(5,35)$. The inoculated indicators were maintained at 28 to $32^{\circ} \mathrm{C}$ for 6 months and were further analyzed as follows. Tissue samples (5 $\mathrm{g}$ of young leaves and stems) were homogenized (Virtis Cyclone IQ2 homogenizer) in $20 \mathrm{ml}$ of extraction medium containing $15 \mathrm{ml}$ of phenol and $5 \mathrm{ml}$ of buffer $(0.4 \mathrm{M}$ Tris- $\mathrm{HCl}$, $\mathrm{pH} 8.9 ; 1 \%$ [wt/vol] sodium dodecyl sulfate [SDS]; 5 mM EDTA, $\mathrm{pH} 7.0 ; 4 \%$ [vol/vol] mercaptoethanol). The total nucleic acids were partitioned in $2 \mathrm{M} \mathrm{LiCl}$, and the soluble fraction was concentrated by ethanol precipitation and resuspended in TKM buffer (10 mM Tris-HCl, $\mathrm{pH} 7.4$; $10 \mathrm{mM} \mathrm{KCl} ; 0.1 \mathrm{mM} \mathrm{MgCl} 2$ ). Aliquots of these preparations ( $20 \mu \mathrm{l}$ was equivalent to $300 \mathrm{mg}$ fresh weight) were subjected to two consecutive rounds of polyacrylamide gel electrophoresis in 5\% gels (sequential PAGE or sPAGE), the first under nondenaturing and the second under denaturing conditions (33). The circular forms of the viroids were viewed by silver staining (22).

Viroid characterization. Tissue samples $(500 \mathrm{mg})$ were placed in sealed plastic bags with a heavy net (Plant Print Diagnostics, Valencia, Spain) containing $5 \mathrm{ml}$ of extraction buffer $(0.1 \mathrm{M}$ Tris- $\mathrm{HCl}, \mathrm{pH}$ 8.0; $50 \mathrm{mM}$ EDTA; $0.5 \mathrm{M} \mathrm{NaCl} ; 10 \mathrm{mM}$ mercaptoethanol) and gently crushed with a manual roller (Plant Print Diagnostics). The homogenate was subjected to alkaline denaturation $(1,6)$, followed by reverse transcription and polymerase chain reaction amplification (RT-PCR) using viroidspecific primer pairs. First-strand cDNA was synthesized at $60^{\circ} \mathrm{C}$ using $27-$ mer primers specific for each viroid and thermoscript reverse transcriptase (Invitrogen, Carlsbad, CA, USA) as described (3). In order to recover full-length viroid DNA, second strand synthesis and DNA amplification were performed using a set of two contiguous forward and reverse primers specific for each viroid (3). Electrophoresis in $2 \%$ agarose gels was used to confirm the synthesis of the expected DNA prod- ucts. The amplified DNAs were sequenced with an ABI PRISM DNA sequencer 377 (Perkin-Elmer, Wellesley, MA, USA).

When the amplified sequence showed heterogeneity, the amplified product was cloned in the pGEM-T vector (Promega, Madison, WI, USA), and a consensus sequence was obtained by sequencing several clones representing the most frequent profiles revealed by single-strand conformation polymorphism (SSCP) analysis (27). Briefly, the cloned sequences were amplified from the cloning vector by PCR, partially denatured, and analyzed by PAGE in $14 \%$ gels, and the DNA bands were visualized by silver staining (22). Multiple sequence alignments were performed with Clustal W (44). The most stable secondary structure was determined with the MFOLD program (circular version) from the GCG package (50) and viewed with the RNAviz program (8).

Northern blot hybridization. RNAs separated by sPAGE were electroblotted (400 $\mathrm{mA}$ for $2 \mathrm{~h}$ ) to positively charged nylon membranes (Roche Applied Science, Basel, Switzerland) using TBE buffer (90 $\mathrm{mM}$ Tris, $90 \mathrm{mM}$ boric acid, and $2 \mathrm{mM}$ EDTA, pH 8.0) and immobilized by UV cross-linking. Viroid-specific DIG-labeled DNA probes were synthesized by PCR from plasmids containing the full-length viroid sequence as described by Palacio et al. (28). Prehybridization $\left(60^{\circ} \mathrm{C}\right.$ for 2 to 4 h) and hybridization $\left(60^{\circ} \mathrm{C}\right.$ overnight $)$ were performed in $50 \%$ formamide and $6 x$ SSPE as described by Sambrook et al. (37). The DIG label was detected with an anti-DIG-alkaline phosphatase conjugate (Fab fragments) and visualized with the chemiluminescence substrate disodium 3-(4-methoxyspiro \{1,2-dioxetane-3,2'-(5'chloro) tricyclo $\left[3.3 .1 .1^{3,7}\right]$ decan $\left.\}-4-y l\right)$ phenyl phosphate (CSPD) (Roche Applied Science).

Field symptom evaluation. Bark symptoms were recorded annually. In 2005, when the experiment was terminated, the trees were decapitated $30 \mathrm{~cm}$ above the bud union, and the bark of the stumps was removed to verify symptoms on the wood above and below the bud union. The stumps were pulled out of the soil, and symptoms below the soil level were also recorded.

Tree growth, fruit yield and quality. Tree height, canopy size, and trunk circumferences of the scion and the rootstock (10 $\mathrm{cm}$ above and below the bud-union line) were measured in 2003. Fruits were harvested manually, and the yield of each tree was recorded from 1997 to 2002. Given the spherical shape of the canopy, its size was calculated as the volume of a sphere: $\mathrm{Vc}=4 / 3 \pi R^{3}, R$ being the radius of the canopy. The value of $R$ was estimated as one-half of the average of the canopy height measurement and two perpendicular width measurements made in the center of the canopy $(45,46)$. In 2003, 12 fruits were randomly collected from each tree and evaluated for fruit weight, fruit size, rind thickness, and juice volume, acidity, soluble solids, color, and maturity index. All data from each citrus species were analyzed by ANOVA using the Statgraphics Plus 5.1. software.

Light microscopy. Root tips were fixed in formalin-acetic acid-alcohol (18:1:1), dehydrated through a graded ethanol series, and embedded in paraffin. The embedded tissues were cut serially every 10 $\mu \mathrm{m}$, stained with safranin, and counterstained with fast-green. To identify the presence of carbohydrates in the cortex cells, the embedded tissues were also stained in Schiff's reagent (24).

In vitro root formation. Four 1-yearold Carrizo citrange seedlings were subjected to microsatellite analysis or SSRs (Simple Sequence Repeat Polymorphism) $(2,9,20,36)$ using seven primer sets (TAA1, TAA15, TAA27, TAA33, TAA41, TAA45, and CAGG9) (25) to confirm their nucellar origin. Individual sets of two seedlings, each set composed of one tree graft inoculated from the Washington navel viroid source and one noninoculated, were maintained at 23 to $25^{\circ} \mathrm{C}$ or at 28 to $32^{\circ} \mathrm{C}$. Six months after inoculation, the plants were decapitated and infection was confirmed by sPAGE analysis as described. The second flush of tissue was used as a source of material for in vitro root formation assay. Explants consisted of 30 stem internodes $(1 \mathrm{~cm}$ long) per treatment prepared and disinfested as described previously (12). Root initiation medium contained inorganic salts (26), $100 \mathrm{mg} /$ liter $i$-inositol, 0.2 $\mathrm{mg} /$ liter thiamine hydrochloride, $1 \mathrm{mg} / \mathrm{liter}$ pyridoxine hydrochloride, $1 \mathrm{mg} /$ liter nicotinic acid, $30 \mathrm{~g} /$ liter sucrose, $10 \mathrm{mg} / \mathrm{liter}$ naphthalene acetic acid (NAA), and 10 g/liter agar (Difco Bacto, Detroit, MI, USA). After culturing the explants in root initiation medium for 45 days, they were transferred to root elongation medium (the same composition as root initiation medium but without NAA) for 15 additional days. The cultures were always maintained in the culture room at $26 \pm 1{ }^{\circ} \mathrm{C}$ and $60 \%$ relative humidity and exposed $16 \mathrm{~h}$ per day to an illumination of $40 \mu \mathrm{E} \mathrm{m} \mathrm{m}^{-2} \mathrm{~s}^{-1}$.

\section{RESULTS}

Characterization of citrus viroids from the field source. The original source of the citrus viroid(s) had been maintained in Washington navel sweet orange, and budwood from this source was graft inoculated on Etrog citron. The sPAGE analysis of the inoculated citron plants demonstrated that the source contained several viroids with the mobilities of CEVd, CBLVd, HSVd, and CDVd (data not shown). A nucleic acid preparation obtained from the Washington navel sweet orange tree was subjected to RT-PCR using primers specific for $\mathrm{CEVd}$, HSVd, CBLVd, CDVd, CBCVd, and CVd-V $(3,43)$. The results confirmed that the 
source contained CEVd, HSVd, CBLVd, and CDVd (data not shown).

The consensus sequence of the CEVd amplicon (GenBank accession EU872276) had 371 nt (Fig. 1A) and $98.1 \%$ identity with a reference sequence (M30868) representative of class A, characterized as severe on the basis of its virulence in tomato (49). The sequence of the $\mathrm{P}_{\mathrm{L}}$ region located within the pathogenicity $(\mathrm{P})$ domain possessed the characteristics of class $A$, while the $P_{R}$ region located in the variable $(V)$ domain had an insertion (+U129) and a transversion (U234 $\rightarrow \mathrm{A})$. These changes resulted in a larger loop in the predicted rod-like secondary structure of the CEVd molecule. The consensus sequence of HSVd (EU872277) was 301 nt (Fig. 1B) with 99.0\% identity with the reference sequence of HSVd (variant IIa) (AF213503) (29,32), and in the $\mathrm{V}$ domain showed the sixnucleotide motif characteristic of the nonpathogenic HSVd sequence citrus variants (32). The consensus sequence of CBLVd (EU872278) was 328 nt (Fig. 1C), with 98.5\% identity with CBLVd (variant Ia) (AF040721) $(19,41)$.

Since attempts to sequence the CDVd amplicon failed, cDNA clones derived from the amplicon were subjected to SSCP analysis (Fig. 1F). The migration of the ssDNAs suggested the existence of at least two subpopulations, with the size of two CDVd variants (variants IIIa and IIIb) (Fig. $1 \mathrm{D}$ and $\mathrm{E})$. Sequencing of four clones con- firmed the presence of at least two sequence variants (EU872279 and EU872280) of 297 and 294 nt, which had 99.3 and $99.7 \%$ identity with the two CDVd variants (variants IIIa and IIIb) (S76452 and AF184147) (31), respectively.

Assessment of viroid infection in inoculated Nules clementine and Navelina sweet orange trees. Inoculated and noninoculated clementine and sweet orange trees grafted on Carrizo citrange rootstocks were established in the field in 1988. Ten years after planting, the four viroids (CEVd, HSVd, CBLVd, and CDVd) present in the inoculum source were detected in all the inoculated trees, whereas the noninoculated trees had remained viroidfree. Samples from three randomly chosen infected clementine trees and three ran- domly chosen infected sweet orange trees were subjected to RT-PCR using primers specific for CEVd, HSVd, CBLVd, and CDVd. The consensus sequences of CEVd, HSVd, and CBLVd obtained by sequencing the amplicons revealed only minor nucleotide changes in comparison with the consensus sequences of the viroid source maintained in Washington navel (data not shown). When the nucleic acid preparations obtained from three sweet orange trees and three clementine trees were separated by SPAGE and subjected to Northern hybridization with a CDVd-specific probe, two bands were observed, with the slow and fast migrating viroid bands corresponding to the mobilities of variants IIIa and IIIb of CDVd, respectively (Fig. 2). The sweet orange trees had similar titers of

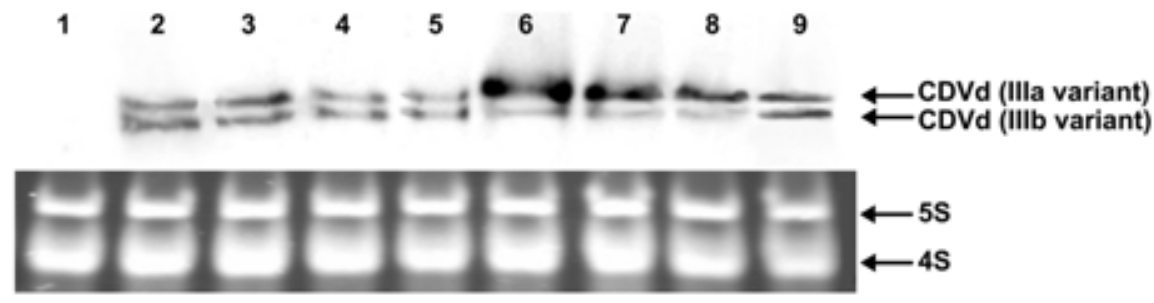

Fig. 2. Results of Northern blot hybridization analysis with a Citrus dwarfing viroid (CDVd)-specific probe. Lanes contain extracts from: 1, noninfected Washington navel sweet orange; 2, infected Washington navel sweet orange used as a source of inoculum; 3-5, infected Navelina sweet orange trees; 68, infected clementine trees; 9, mixture of CDVd variants IIIa and IIIb from infected Etrog citron. Each variant is identified in the right margin. The $5 \mathrm{~S}$ and $4 \mathrm{~S}$ RNAs visualized in the ethidium bromide stained gel are shown to illustrate comparative amounts of material in each lane.
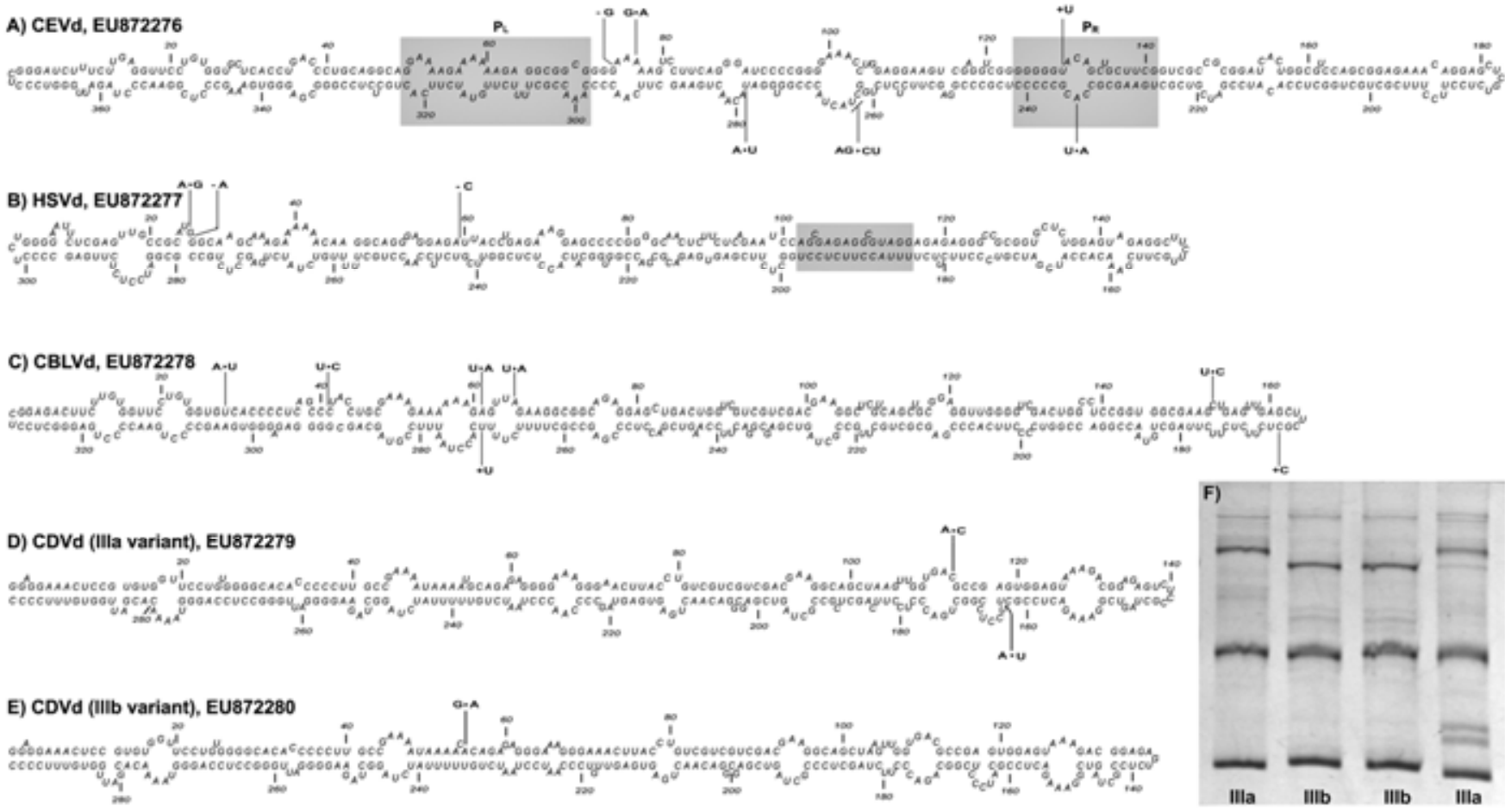

Fig. 1. Primary and secondary structure of the consensus sequences of A, Citrus exocortis viroid (CEVd), B, Hop stunt viroid (HSVd), and C, Citrus bent leaf viroid (CBLVd) were obtained by sequencing the reverse transcription-polymerase chain reaction (RT-PCR) amplicons. Sequences of two Citrus $d w a r f-$ ing viroid (CDVd) variants, D, (IIIa) and $\mathbf{E}$, (IIIb), were generated from the sequences of four independent clones selected according to the $\mathbf{F}$, single-strand conformation polymorphism (SSCP) profiles. Sequences were compared with the reference sequences of CEVd (type A) (49), HSVd (variant IIa) (29,32), CBLVd (19,41), and CDVd (variants IIIa and IIIb) (31) (GenBank accessions M30868, AF213503, AF040721, S76452, and AF184147, respectively). The $\mathrm{P}_{\mathrm{L}}$ and $\mathrm{P}_{\mathrm{R}}$ regions of CEVd and the "cachexia expression motif" of HSVd are shown shaded. Positions at which the derived sequences differ from the reference sequences are indicated by connecting lines above and below the sequence showing the variant nucleotide at that position. 

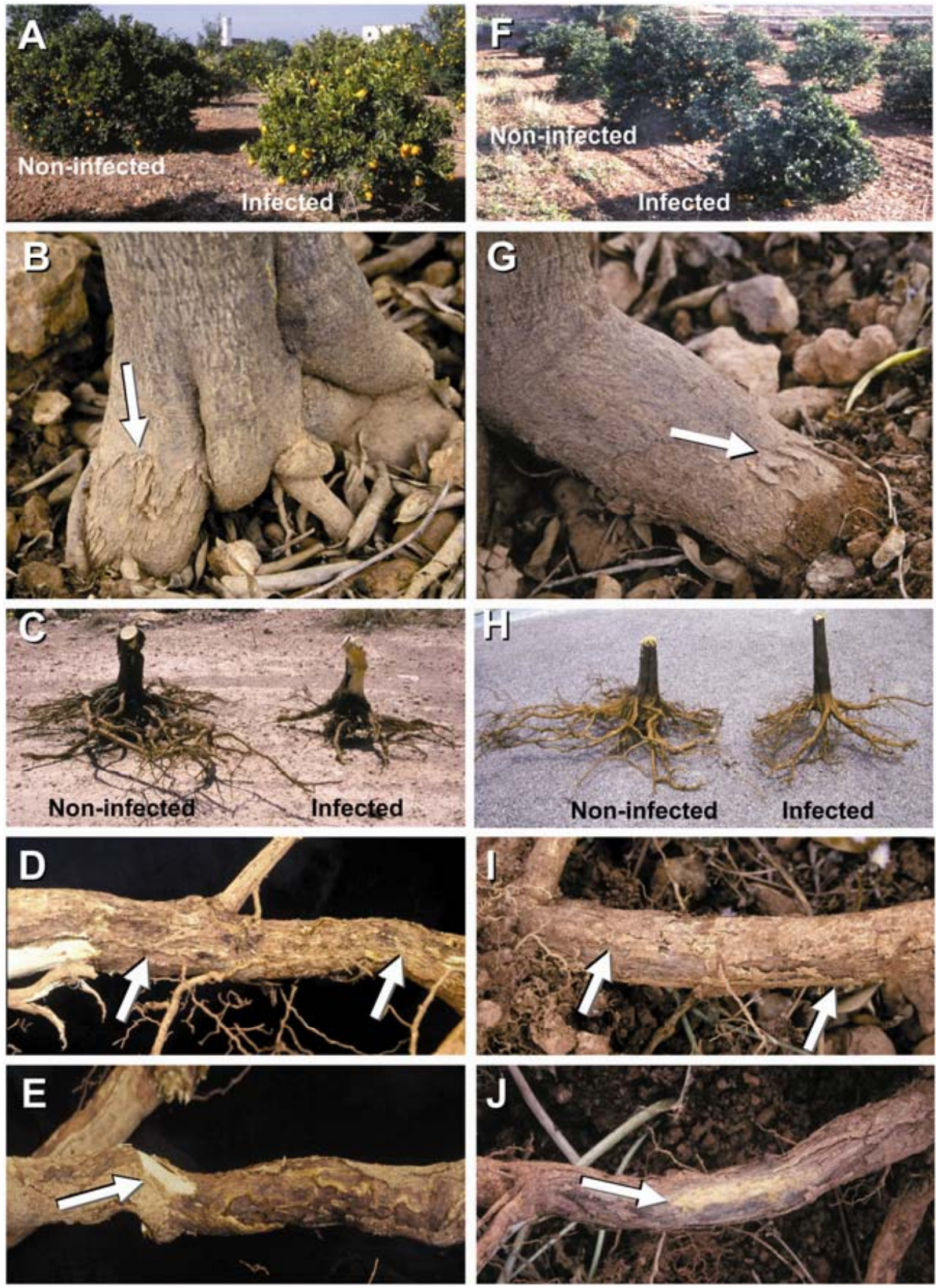

Fig. 3. A to E, Symptoms of Nules clementine trees, and $\mathbf{F}$ to J, Navelina sweet orange trees grafted on Carrizo citrange. A and F, Comparison of overall growth of infected and noninfected trees. B and G, Small scales (indicated by arrows) observed below the soil level on Carrizo citrange rootstock of infected trees. C and $\mathbf{H}$, Comparison of root systems from infected and noninfected trees. D and I, Scales and dark lesions (indicated by arrows) on infected roots. $\mathbf{E}$ and $\mathbf{J}$, Arrows point to absence of gum deposits in wood of roots after scraping away the bark. 
IIIa and IIIb variants (Fig. 2, lanes 3 to 5), whereas in clementine trees (Fig. 2, lanes 6 to 8 ) the titers of variant IIIa were higher than those of variant IIIb.

Effect of infection on tree size, yield, and fruit quality. In general, infected trees were smaller than the noninfected controls (Fig. 3A and F), the difference being more important in clementine trees. As shown in Table 1, statistical analysis of tree size parameters (height, canopy volume, rootstock, and scion circumferences) recorded in 2003 when the experiment was terminated, showed that measurements for all parameters on infected clementine trees were significantly smaller than on the noninfected trees, whereas in the case of sweet orange the differences were significant only for rootstock and scion circumferences. As shown in Table 2, except for 1997 for Nules clementine, the fruit yield of infected trees of both species was significantly smaller each year than that of the noninfected controls. Over six seasons (1997 to 2002), cumulative yields of infected clementine and sweet orange trees were only 57.4 and $67.0 \%$, respectively, of those of the corresponding noninfected controls.

As summarized in Table 3, viroid infection affected the characteristics of fruits. For Nules clementine, rind thickness, maturity index, juice volume, fruit height, and color index values were not significantly different between treatments (Table 3). Average weight and diameter of fruits from infected trees were significantly larger, whereas values for fruit density, fruit shape, juice density, soluble solids, and acidity were larger for fruits from uninfected trees. For Navelina sweet orange, values for fruit density, shape, color index, and rind thickness were not significantly different between treatments. Values for average fruit weight, height, diameter, and juice volume maturity were significantly greater for fruits from infected trees, whereas values for juice density, soluble solids, and acidity were significantly greater for fruits from uninfected trees.

Symptoms. No bark scaling symptoms were observed in the trunk of the Carrizo citrange rootstock of the clementine and sweet orange trees. However, after remov- ing the soil around the trees, the infected trees of both species showed small scales on the main roots of the Carrizo citrange rootstock (Fig. 3B and G). After decapitating the canopy at about $30 \mathrm{~cm}$ above the bud-union line and removing the bark from the remaining trunk, no symptoms were observed in the wood below or above the bud union. Observations of the root system after the stumps were pulled out of the soil

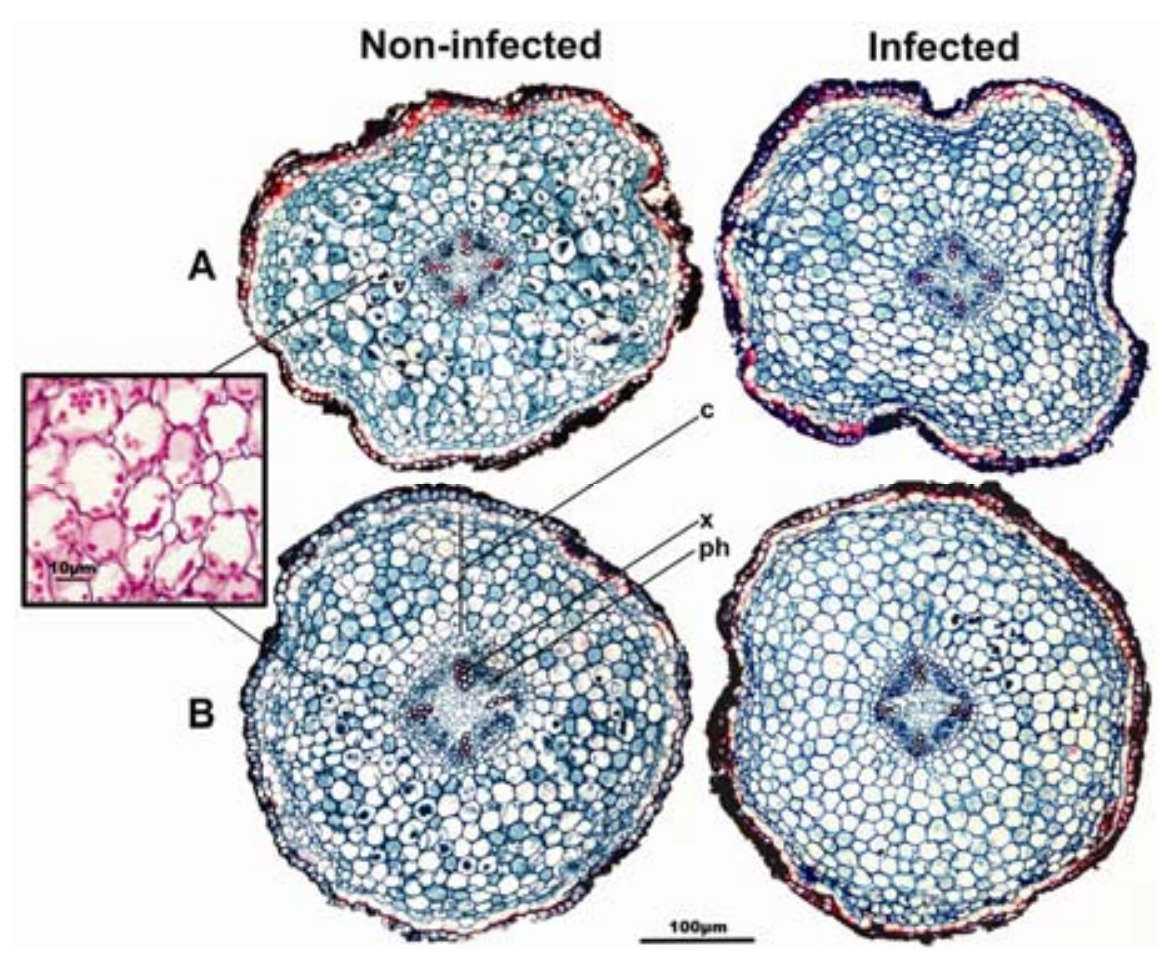

Fig. 4. Histological sections of fibrous roots of Carrizo citrange rootstocks from noninfected (left) and infected (right) A, Nules clementine trees, and $\mathbf{B}$, Navelina sweet orange trees showing the characteristic arrangement of phloem strands (ph) alternating with xylem ridges (x). The cortex cells (c) of noninfected trees (left) contain dark stained bodies that are very scarce in roots of infected trees (right). The left inset shows these bodies stained an intense purplish red after Schiff's (PAS) reaction. Scale bar at the bottom indicates $100-\mu \mathrm{m}$ increments.

Table 1. Effect of a field-source mixture of Citrus exocortis viroid (CEVd), Hop stunt viroid (HSVd), Citrus bent leaf viroid (CBLVd), and Citrus dwarfing viroid $(\mathrm{CDVd})$ on the size of infected Nules clementine and Navelina sweet orange trees grafted on Carrizo citrange ${ }^{\mathrm{z}}$

\begin{tabular}{|c|c|c|c|c|c|c|}
\hline \multirow[b]{2}{*}{ Tree size parameters } & \multicolumn{3}{|c|}{ Nules clementine } & \multicolumn{3}{|c|}{ Navelina sweet orange } \\
\hline & Noninfected & Infected & $P$ value & Noninfected & Infected & $P$ value \\
\hline Tree height (m) & $2.0 \pm 0.1$ & $1.6 \pm 0.1$ & 0.0011 & $1.4 \pm 0.1$ & $1.3 \pm 0.1$ & 0.1157 \\
\hline Canopy volume $\left(\mathrm{m}^{3}\right)$ & $3.2 \pm 0.3$ & $1.4 \pm 0.1$ & 0.0000 & $1.4 \pm 0.1$ & $1.2 \pm 0.2$ & 0.3462 \\
\hline Rootstock circumference $(\mathrm{cm})$ & $40.9 \pm 1.3$ & $33.0 \pm 1.1$ & 0.0001 & $36.1 \pm 0.9$ & $29.7 \pm 1.2$ & 0.0002 \\
\hline Scion circumference $(\mathrm{cm})$ & $36.4 \pm 1.3$ & $29.9 \pm 0.7$ & 0.0010 & $35.4 \pm 1.6$ & $29.5 \pm 1.4$ & 0.0098 \\
\hline
\end{tabular}

${ }^{\mathrm{z}}$ Data were subjected to ANOVA. Numbers are mean \pm standard error.

Table 2. Effect of a field-source mixture of Citrus exocortis viroid (CEVd), Hop stunt viroid (HSVd), Citrus bent leaf viroid (CBLVd), and Citrus dwarfing viroid (CDVd) on fruit yield of infected Nules clementine and Navelina sweet orange trees grafted on Carrizo citrange ${ }^{\mathrm{z}}$

\begin{tabular}{|c|c|c|c|c|c|c|}
\hline \multirow[b]{2}{*}{ Fruit yield (kg)/year } & \multicolumn{3}{|c|}{ Nules clementine } & \multicolumn{3}{|c|}{ Navelina sweet orange } \\
\hline & Noninfected & Infected & $P$ value & Noninfected & Infected & $P$ value \\
\hline 1997 & $3.8 \pm 0.9$ & $2.9 \pm 0.6$ & 0.4056 & $17.9 \pm 1.8$ & $11.9 \pm 1.9$ & 0.0285 \\
\hline 1998 & $8.6 \pm 1.7$ & $4.6 \pm 0.9$ & 0.0440 & $14.9 \pm 2.1$ & $9.4 \pm 1.5$ & 0.0432 \\
\hline 1999 & $26.0 \pm 3.7$ & $14.0 \pm 1.6$ & 0.0053 & $15.6 \pm 2.1$ & $10.0 \pm 1.4$ & 0.0337 \\
\hline 2000 & $26.7 \pm 4.1$ & $9.4 \pm 1.8$ & 0.0005 & $7.7 \pm 1.1$ & $4.9 \pm 0.8$ & 0.0468 \\
\hline 2001 & $48.6 \pm 4.2$ & $27.9 \pm 2.5$ & 0.0002 & $29.7 \pm 3.3$ & $19.1 \pm 1.9$ & 0.0089 \\
\hline 2002 & $27.0 \pm 2.8$ & $19.1 \pm 1.5$ & 0.0175 & $21.1 \pm 3.3$ & $15.5 \pm 1.9$ & 0.1513 \\
\hline Cumulative yield $(\mathrm{kg})$ & $135.6 \pm 12.6$ & $77.9 \pm 6.5$ & 0.0001 & $105.8 \pm 10.4$ & $70.9 \pm 7.8$ & 0.0111 \\
\hline
\end{tabular}

${ }^{\mathrm{z}}$ Data were subjected to ANOVA. Numbers are the mean \pm standard error. 
showed that infected trees of both scions had a visibly smaller root system than their noninfected counterparts (Fig. 3C and $\mathrm{H}$ ). Additionally, the roots of infected trees presented scales and dark lesions (Fig. 3D and I) never observed on the roots of noninfected trees. Such lesions resembled those of Phytophthora root rot; however, unlike Phytophthora lesions, they were dry and devoid of gum exudates. No gum deposits in the wood were observed after scraping away the bark (Fig. 3E and J).

No histological abnormalities were observed in mature fibrous roots from infected trees, which showed the arrangement of four primary phloem strands alternating with xylem ridges characteristic of roots from noninfected trees (Fig. 4A and $\mathrm{B}$, left panels). However, the storage parenchyma cells of the root cortex of noninfected trees (Fig. 4A and B, indicated by $\mathrm{c}$ in the left panels) contained numerous dark-stained bodies that were very scarce in the cortex of infected trees (Fig. 4A and $\mathrm{B}$, right panels). As shown by the Periodic Acid - Schiff's (PAS) reaction, which is a specific staining for carbohydrates, these bodies had an intense purplish-red stain, confirming that they were amyloplasts accumulating in the storage parenchyma (Fig. 4, left inset). The number of amyloplasts in the root cortex was estimated in a random selection of three sections from six independent roots. Statistical analysis showed significant differences (Pearson Gi-dos, $P \leq 0.01$ ) between infected (average: 12.5 cells with amyloplasts per section) and noninfected (average: 26.0 cells with amyloplasts per section) sweet orange trees grafted on Carrizo citrange, and between infected (average: 7.3 cells with amyloplasts per section) and noninfected (average: 29.6 cells with amyloplasts per section) clementine trees grafted on Carrizo citrange.

Root formation in vitro. An in vitro assay was designed to estimate the effect of viroid infection on the capacity of Carrizo citrange explants to regenerate roots. In order to avoid the use of seedling plants that were not true-to-type, leaf samples were subjected to SSR analysis to confirm their nucellar origin. Ploidy analysis confirmed that none of the plants were autotetraploid (data not shown), an abnormality that is not infrequent in the progeny of diploid Carrizo citrange trees (38). Two sets of two seedlings each (one graft inoculated and one noninoculated control) were maintained at 22 to $25^{\circ} \mathrm{C}$ or at 28 to $32^{\circ} \mathrm{C}$, and 6 months after inoculation the nucleic acid extracts from these plants were subjected to SPAGE analysis to confirm infection (Fig. 5A, lanes 1 and 3). Based on visual assessment of a comparison to a dilution series of viroid extract from seedlings maintained at 28 to $32^{\circ} \mathrm{C}$ (Fig. 5B, lanes 2 to 7), the viroid titers in the Carrizo citrange seedlings maintained at 22 to $25^{\circ} \mathrm{C}$ were estimated to be one-hundred and fivefold less for CEVd and CBLVd, respectively, and two-fold less for HSVd and CDVd compared to titers in seedlings maintained at 28 to $32^{\circ} \mathrm{C}$ (Fig. 5B).

The in vitro cultured stem-segment explants (30 explants per treatment in two separate assays) developed root primordia after 4 weeks in culture. After 45 days, they were transferred to elongation medium to assess root growth. For explants from seedlings grown at 22 to $25^{\circ} \mathrm{C}$, there was no significant difference in percentage of explants with roots between infected and noninfected seedlings (Table 4). For explants collected from seedlings grown at 28 to $32^{\circ} \mathrm{C}$, the number of infected explants that produced roots was significantly lower $(42.3 \%)$ than in the case of noninfected explants $(89.2 \%)$ (Table 4, Fig. 6).

Multifactor ANOVA of the number of roots per explant and average root length revealed that the number and length of the roots were affected as a result of infection $(F=22.12 ; P \leq 0.0001)$ as well as by the temperature at which the Carrizo citrange seedlings used as the source of explants were grown $(F=53.77 ; P \leq 0.0001)$, with a significant reduction in root production in infected plants grown at 28 to $32^{\circ} \mathrm{C}$ and in root length due to infection regardless of

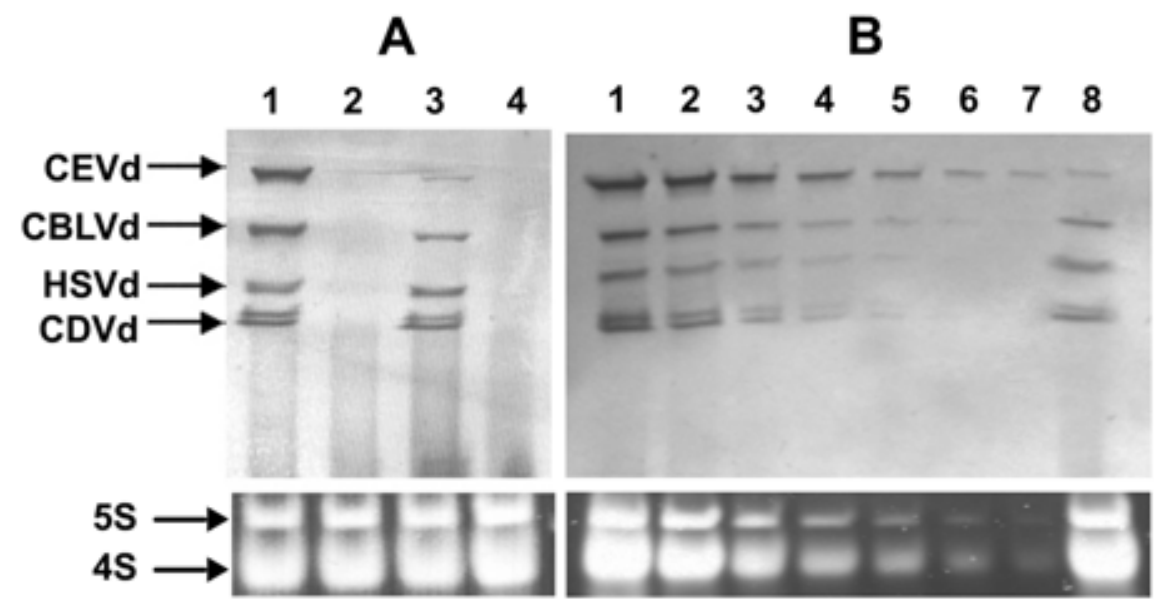

Fig. 5. A, Sequential polyacrylamide gel electrophoresis (sPAGE) analysis of nucleic acid extracts from inoculated (lanes 1, 3) and noninoculated (lanes 2, 4) Carrizo citrange seedlings grown at 28$32^{\circ} \mathrm{C}$ (lanes 1,2 ) and at $22-25^{\circ} \mathrm{C}$ (lanes 3,4 ). B, Sequential PAGE analysis of nucleic acid extracts from inoculated Carrizo citrange seedlings grown at $28-32^{\circ} \mathrm{C}$; undiluted extract (lane 1) and extracts diluted $1 / 2,1 / 5,1 / 10,1 / 20,1 / 50,1 / 100$ (lanes $2-7$, respectively) or undiluted extract from inoculated seedlings grown at $22-25^{\circ} \mathrm{C}$ (lane 8). $4 \mathrm{~S}$ RNAs and 5S RNAs (B, diluted as indicated for each respective lane) visualized in the ethidium bromide stained gel are shown to illustrate comparative amounts of nucleic acid loaded in each lane.

Table 3. Effect of a field-source mixture of Citrus exocortis viroid (CEVd), Hop stunt viroid (HSVd), Citrus bent leaf viroid (CBLVd), and Citrus dwarfing viroid (CDVd) on the quality of fruit from infected Nules clementine and Navelina sweet orange trees grafted on Carrizo citrange ${ }^{\mathrm{Z}}$

\begin{tabular}{|c|c|c|c|c|c|c|}
\hline \multirow[b]{2}{*}{ Fruit quality parameters } & \multicolumn{3}{|c|}{ Nules clementine } & \multicolumn{3}{|c|}{ Navelina sweet orange } \\
\hline & Noninfected & Infected & $P$ value & Noninfected & Infected & $P$ value \\
\hline Average fruit weight $(\mathrm{g})$ & $104.7 \pm 3.0$ & $114.0 \pm 2.5$ & 0.0222 & $199.6 \pm 5.0$ & $233.9 \pm 6.1$ & 0.0001 \\
\hline Fruit density $\left(\mathrm{g} \mathrm{ml}^{-1}\right)$ & $0.9 \pm 0.0$ & $0.8 \pm 0.0$ & 0.0016 & $0.9 \pm 0.0$ & $0.9 \pm 0.0$ & 0.5151 \\
\hline Fruit height (mm) & $50.6 \pm 0.4$ & $51.7 \pm 0.6$ & 0.1219 & $71.9 \pm 0.8$ & $76.7 \pm 1.1$ & 0.0011 \\
\hline Fruit diameter $(\mathrm{mm})$ & $63.3 \pm 0.6$ & $66.2 \pm 0.6$ & 0.0025 & $73.8 \pm 0.6$ & $77.5 \pm 0.7$ & 0.0005 \\
\hline Fruit shape (diameter/height) & $1.4 \pm 0.0$ & $1.3 \pm 0.0$ & 0.0161 & $1.0 \pm 0.0$ & $1.0 \pm 0.0$ & 0.2213 \\
\hline Color index & $15.9 \pm 0.5$ & $14.8 \pm 0.4$ & 0.1026 & $14.3 \pm 0.4$ & $14.7 \pm 0.4$ & 0.4628 \\
\hline Rind thickness (mm) & $2.5 \pm 0.1$ & $2.5 \pm 0.1$ & 0.7165 & $4.8 \pm 0.1$ & $5.3 \pm 0.4$ & 0.1733 \\
\hline Volume of juice $(\mathrm{ml})$ & $541.7 \pm 17.6$ & $577.8 \pm 11.9$ & 0.0020 & $986.9 \pm 58.2$ & $1245.6 \pm 36.7$ & 0.0006 \\
\hline Density of juice $\left(\mathrm{g} \mathrm{ml}^{-1}\right)$ & $1.1 \pm 0.0$ & $1.0 \pm 0.0$ & 0.0000 & $1.052 \pm 0.0$ & $1.047 \pm 0.0$ & 0.0247 \\
\hline Soluble solids (\%) & $14.9 \pm 0.1$ & $13.0 \pm 0.1$ & 0.0000 & $14.1 \pm 0.2$ & $13.3 \pm 0.2$ & 0.0120 \\
\hline Acidity & $9.0 \pm 0.2$ & $7.6 \pm 0.1$ & 0.0000 & $12.0 \pm 0.4$ & $10.3 \pm 0.2$ & 0.0011 \\
\hline Maturity index & $17.7 \pm 0.3$ & $17.1 \pm 0.4$ & 0.4430 & $11.9 \pm 0.4$ & $13.0 \pm 0.3$ & 0.0420 \\
\hline
\end{tabular}

${ }^{\mathrm{z}}$ Data were subjected to ANOVA. Numbers are the mean \pm standard error. 
the temperature at which seedlings were grown (Table 4). In addition, a synergistic interaction was found between the two factors (infection and temperature) $(F=$ 28.74; $P \leq 0.0001$ ), a result that is in full agreement with the higher titers reached by CEVd and CBLVd in plants growing at 28 to $32^{\circ} \mathrm{C}$ rather than at 22 to $25^{\circ} \mathrm{C}$ (Fig. 5). Table 4 illustrates how infection affected the three rooting parameters studied.

\section{DISCUSSION}

Citrus exocortis disease, caused by CEVd, was described in 1948 as a "bark shelling or scaling" disorder of the trifoliate orange (Poncirus trifoliata (L.) Raf.) rootstock of grafted trees, which also showed marked dwarfing (17). When Etrog citron (Citrus medica L.) was later used as an indicator for exocortis disease indexing, a variety of symptoms, ranging from severe to very mild, were erroneously considered, for many years, as evidence for the occurrence of CEVd strains. However, the identification and biological characterization of additional viroids, naturally occurring in citrus, has shown that each viroid induces specific symptoms not only on Etrog citron (14), but also on trees grafted on trifoliate orange and trifoliate orange hybrid rootstocks $(41,45,47)$. Except for orchards established with certified viroid-free nursery plants, field trees are usually coinfected with several viroids, a situation that prevented identification of symptoms expressed by specific viroids in commercial species and cultivars. Only recently, the attenuation or enhancement of viroid-induced effects due to inoculum of known composition could be studied and elucidated in field grown clementine trees grafted on trifoliate orange rootstocks (46). The viroid field source characterized in the present study was found to contain CEVd, HSVd, CBLVd, and two distinct variants of CDVd, a combination of viroids that previously had been found to result in synergistic viroid interactions, and which caused in addition to the expected severe rootstock bark-scaling, a most dramatic effect on tree size and fruit yield of clementine trees grafted on trifoliate orange rootstock (46).

In the present study, infected trees did not show the severe bark-scaling symptoms characteristic of exocortis disease, but the roots were affected by small lesions and scales never reported before. Even though the CEVd variant in the inoculum source was characterized as a class A member with the pathogenic determinants of CEVd variants that induce severe symptoms in tomato $(48,49)$ and in trifoliate orange (45), the observed symptoms were found to be mild in Carrizo citrange. These symptoms could be unexpectedly mild because Carrizo citrange is less sensitive to the effects of CEVd than is trifoliate orange, as well as to the relatively mild climatic conditions where the trials were conducted. In fact, in the same region, we have noticed similar mild symptoms in CEVd-infected field trees on Carrizo or Troyer citrange rootstocks (unpublished data). However, and more importantly, in spite of the mild symptoms observed in the rootstock, the infected trees were generally smaller and produced reduced yields with smaller fruit size and poorer fruit quality in comparison with noninfected trees. Earlier studies on using viroids to control tree size in high-density plantings showed a similar marked effect of viroid infection in tree growth, canopy size, and yield $(21,30,41)$. Fruit quality was affected in lemon trees (4) but not in sweet orange $(21,30)$. The discrepancy observed in this and past studies regarding the effect on sweet orange might be due to the specific viroid combination used in the present study that was not used in previous dwarfing assays.

The performance of a normal healthy tree is based on an adequate balance between the canopy manufacturing carbohydrates and other photosynthesis products, and the root system supplying water and mineral nutrients. In other words, the size of the canopy reflects the size of the root system and vice versa. In the case of grafted trees, this balance is also affected by the degree of compatibility between the rootstock and the scion. In the case of viroid-infected trees made of viroidtolerant cultivars such as sweet orange or clementine on viroid-sensitive rootstocks

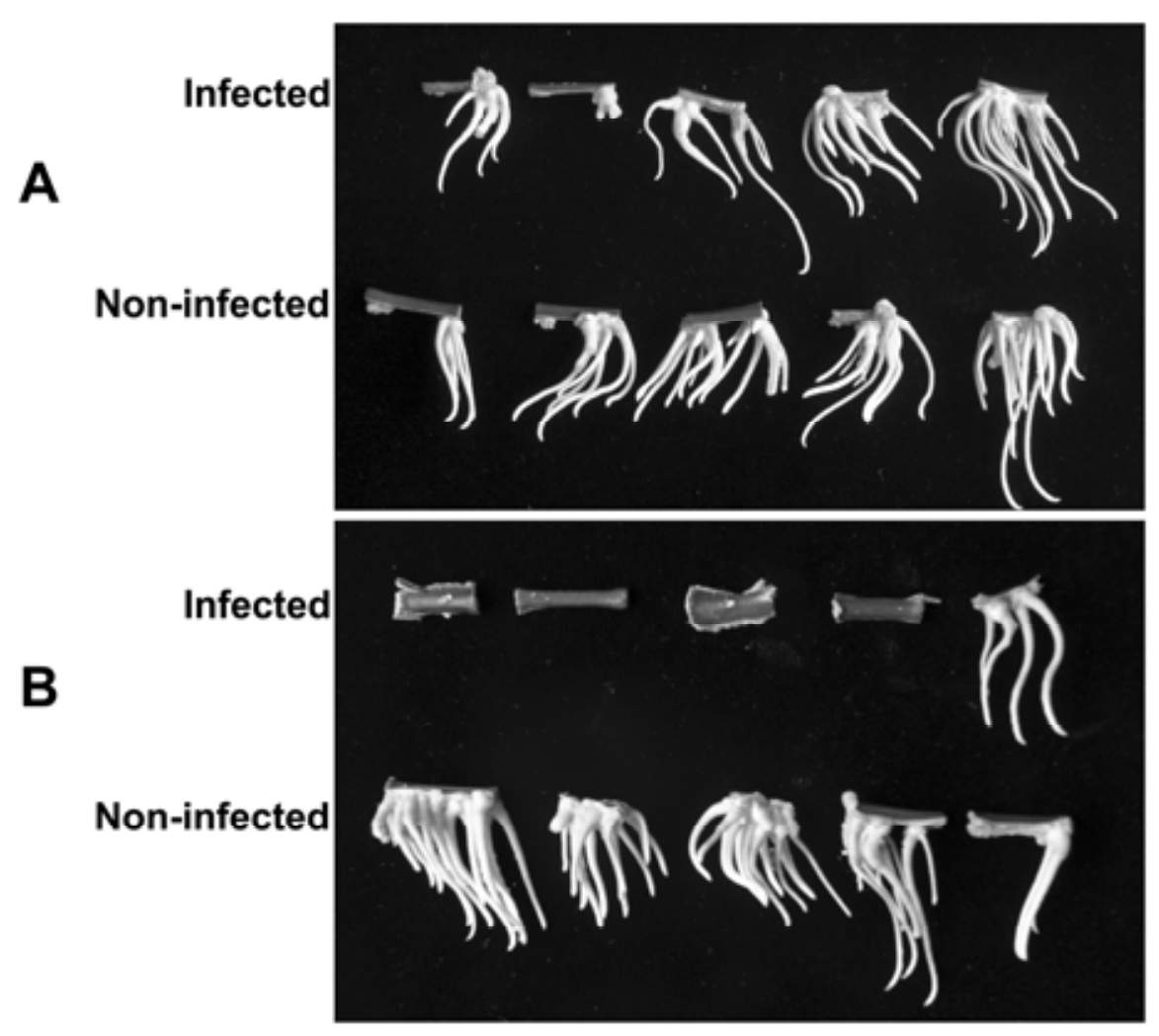

Fig. 6. Root formation on in vitro cultured explants from infected and noninfected Carrizo citrange seedlings grown at $\mathbf{A}, 22-25^{\circ} \mathrm{C}$ or at $\mathbf{B}, 28-32^{\circ} \mathrm{C}$.

Table 4. Effect of a field-source mixture of Citrus exocortis viroid (CEVd), Hop stunt viroid (HSVd), Citrus bent leaf viroid (CBLVd), and Citrus dwarfing viroid $(\mathrm{CDV})$ on root formation of infected Carrizo citrange explants cultured in vitro ${ }^{\mathrm{z}}$

\begin{tabular}{|c|c|c|c|c|c|c|}
\hline \multirow[b]{3}{*}{ Rooting parameters } & \multicolumn{6}{|c|}{ Incubation of Carrizo citrange plants } \\
\hline & \multicolumn{3}{|c|}{$22-25^{\circ} \mathrm{C}$} & \multicolumn{3}{|c|}{$28-32{ }^{\circ} \mathrm{C}$} \\
\hline & Noninfected & Infected & $P$ value & Noninfected & Infected & $P$ value \\
\hline Explants with roots (\%) & 95.0 & 96.3 & 0.8528 & 89.2 & 42.3 & 0.0086 \\
\hline Number of roots/explant & $9.9 \pm 0.6$ & $10.3 \pm 0.7$ & 0.6587 & $8.7 \pm 0.7$ & $2.6 \pm 0.5$ & 0.0000 \\
\hline Average root length $(\mathrm{cm})$ & $2.0 \pm 0.0$ & $1.8 \pm 0.0$ & 0.0000 & $1.7 \pm 0.0$ & $1.0 \pm 0.1$ & 0.0000 \\
\hline
\end{tabular}

${ }^{\mathrm{z}}$ Data are the average of two separate assays in which 30 explants per treatment were cultured. Data were subjected to ANOVA. Numbers are the mean \pm standard error. 
such as Carrizo citrange, the results of the present study have shown that these trees have an underdeveloped root system as well as a smaller canopy than noninfected trees. The cortex of fibrous roots from infected trees had a smaller number of parenchyma cells containing stored carbohydrates compared to noninfected trees. The low amount of stored carbohydrates probably reflects the poor performance and scion/rootstock imbalance of viroidinfected trees.

Early studies from in vitro cultures of CEVd-infected tomato explants showed that root formation was impaired (15). Similar results were obtained in the present study when explants from viroid-infected Carrizo citrange seedlings were cultured in root induction medium. Most explants collected from seedlings growing at 22 to $25^{\circ} \mathrm{C}$ produced roots regardless of whether the plants were infected or not. However, in the case of explants that had been collected from seedlings growing at 28 to $32^{\circ} \mathrm{C}$, the number of infected explants that produced roots was twice as low as in the case of noninfected explants. In addition, root development (number of roots per explant and average root length) was lower in viroid infected explants, in particular when they came from the infected seedlings grown at the higher temperature. Interestingly, in these "high temperature" seedlings, the titers of CEVd and CBLVd as judged by the intensity of the viroid bands in the sPAGE analysis, were higher than those in the "low temperature" seedlings. Therefore, the hindered root development characteristic of the explants from the "high temperature" seedlings could be due to the higher viroid titers.

The hindered root development shown by in vitro grown explants from the "high temperature" Carrizo citrange seedlings mimics the poor root development shown by the viroid infected clementine and sweet orange field trees grafted on Carrizo citrange rootstocks, as reported here. Therefore, in vitro assays on root development, similar to those reported here, might be a quick aid to evaluate rootstock sensitivity to viroid infection.

\section{ACKNOWLEDGMENTS}

This work was supported by grants RTA01-119 and AGL2005-01469 from the Ministerio de Ciencia y Tecnología (Spain). S. M. Bani Hashemian, P. Serra, and C. J. Barbosa are recipients of fellowships from the Iran Citrus Research Institute, the Instituto Valenciano de Investigaciones Agrarias (IVIA), and the Empresa Brasileira de Pesquisa Agropecuaria (EMBRAPA), respectively. The authors thank J. M. Bové for critical reading of the manuscript and Rosario Carbó for technical assistance.

\section{LITERATURE CITED}

1. Astruc, N., Marcos, J. F., Macquaire, G., Candresse, T., and Pallás, V. 1986. Studies of diagnosis of hop stunt viroid in fruit trees: Detection by molecular hybridisation and relationship with specific maladies affecting peach and pear trees. Eur. J. Plant Pathol. 102:837-846.

2. Benbouza, H., Jacquemin, J. M., Baudoin, J. P., and Mergeai, G. 2006. Optimization of a reliable, fast, cheap and sensitive silver staining method to detect SSr markers in polyacrylamide gels. Biotechnol. Agron. Soc. Environ. 10:77-81.

3. Bernad, L., and Duran-Vila, N. 2006. A novel RT-PCR approach for detection and characterization of citrus viroids. Mol. Cell. Probes 20:105-113.

4. Broadbent, P., Gillings, M. R., and Gollow, B. I. 1988. Graft-transmissible dwarfing in Australian citrus. Pages 219-225 in: Proc. Conf. Int. Organ. Citrus Virol. 10th. IOCV, Riverside, CA.

5. Calavan, E. C. 1968. Exocortis. Pages 23-34 in: Indexing procedures for 15 virus diseases of citrus trees. U.S. Dep. Agric. Agric. Res. Serv. Agric. Handb. No.33.

6. Cañizares, M. C., Marcos, J. F., and Pallás, V. 1998. Studies on the incidence of hop stunt viroid in apricot trees (Prunus Americana) by using an easy and short extraction method to analyze a large number of samples. Acta Hortic. 472:581-585.

7. Childs, J. F. L. 1950. The cachexia disease of Orlando tangelo. Plant Dis. Rep. 34:295-298.

8. De Rijk, P., and De Wachter, R. 1997. RnaViz, a program for the visualization of RNA secondary structure. Nucleic Acids Res. 25:46794684.

9. Dellaporta, S. L., Wood, J., and Hicks, J. B. 1983. A plant DNA minipreparation: Version II. Plant Mol. Biol. Rep. 1:19-21.

10. Diener, T. O. 1971. Potato spindle tuber "virus" IV. A replicating, low molecular weight RNA. Virology 45:411-428.

11. Duran-Vila, N., Flores, R., and Semancik, J. S. 1986. Characterization of viroid-like RNAs associated with the citrus exocortis syndrome. Virology 150:75-84.

12. Duran-Vila, N., Ortega, V., and Navarro, L. 1989. Morphogenesis and tissue culture of three citrus species. Plant Cell Tissue Organ Cult. 16:123133.

13. Duran-Vila, N., Pina, J. A., and Navarro, L. 1993. Improved indexing of citrus viroids. Pages 202-211 in: Proc. Conf. Int. Organ. Citrus Virol. 12th. IOCV, Riverside, CA.

14. Duran-Vila, N., Roistacher, C. N., RiveraBustamante, R., and Semancik, J. S. 1988. A definition of citrus viroid groups and their relationship to the exocortis disease. J. Gen. Virol. 69:3069-3080.

15. Duran-Vila, N., and Semancik, J. S. 1982. Effects of exogenous auxins on tomato tissues infected with the citrus exocortis viroid. Phytopathology 72:777-781.

16. Duran-Vila, N., and Semancik, J. S. 1990. Variations on the "cross protection" effect between two strains of citrus exocortis viroid. Ann. Appl. Biol. 17:367-377.

17. Fawcett, H. S., and Klotz, L. J. 1948. Exocortis on trifoliate orange. Citrus Leaves 28:8.

18. Flores, R., Hernández, C., Martínez de Alba, A. E., Daròs, J. A., and Di Serio, F. 2005. Viroids and viroid-host interactions. Annu. Rev. Phytopathol. 43:117-139.

19. Foissac, X., and Duran-Vila, N. 2000. Characterization of two citrus apscaviroids isolated in Spain. Arch. Virol. 145:1975-1983.

20. Froelicher, Y., Bassene, J. P., Jedidl-Neji, E., Morillon, R., Bernardini, G., Constantino, G., and Ollitrault, P. 2007. Induced parthenogenesis in mandarin: Induction procedures and genetic analysis of plantlets. Plant Cell Rep. 26:937-944.

21. Hutton, R. J., Broadbent, P., and Bevington, K. B. 2000. Viroid dwarfing from high density citrus plantings. Hortic. Rev. 24:277-317.

22. Igloi, G. L. 1983. Silver stain for the detection of nanogram amounts of tRNA following two- dimensional electrophoresis. Anal. Biochem. 134:184-188.

23. Ito, T., Ieki, H., Ozaki, K., and Ito, T. 2001. Characterization of a new citrus viroid species tentatively termed Citrus viroid OS. Arch. Virol. 146:975-982.

24. Jensen, W. A. 1962. Botanical histochemistry, principles and practice. W.H. Freeman and Co., San Francisco.

25. Kijas, J. M. H., Thomas, M. R., Fowler, J. C. S., and Roose, M. I. 1997. Integration of trinucleotide microsatellites into a linkage map of Citrus. Theor. Appl. Genet. 94:701-706.

26. Murashige, T., and Skoog, F. 1962. A revised medium for rapid growth and bioassay with tobacco tissue cultures. Physiol. Plant. 15:473479.

27. Palacio, A., and Duran-Vila, N. 1999. Singlestrand conformation polymorphism (SSCP) analysis as a tool for viroid characterisation. J. Virol. Methods 77:27-36.

28. Palacio, A., Foissac, X., and Duran-Vila, N. 2000. Indexing of citrus viroids by imprint hybridisation. Eur. J. Plant Pathol. 105:897-903.

29. Palacio-Bielsa, A., Romero-Durbán, J., and Duran-Vila, N. 2004. Characterization of citrus HSVd isolates. Arch. Virol. 149:537-552.

30. Polizzi, G., Albanese, G., Azzaro, A., Davino, M., and Catara, A. 1991. Field evaluation of dwarfing effect of two combinations of citrus viroids on different citrus species. Pages 230233 in: Proc. Conf. Int. Organ. Citrus Virol. 11 th. IOCV, Riverside, CA.

31. Rakowski, A. G., Szychowski, J. A., Avena, Z. S., and Semancik, J. S. 1994. Nucleotide sequence and structural features of the Group III citrus viroids. J. Gen. Virol. 75:3581-3584.

32. Reanwarakorn, K., and Semancik, J. S. 1998. Regulation of pathogenicity in hop stunt viroid related group II citrus viroids. J. Gen. Virol. 79:3163-3171.

33. Rivera-Bustamante, R. F., Gin, R., and Semancik, J. S. 1986. Enhanced resolution of circular and linear molecular forms of viroid and viroid-like RNA by electrophoresis in a discontinuous-pH system. Anal. Biochem. 156:9195.

34. Roistacher, C. N., Blue, R. L., and Calavan, E. C. 1973. A new test for citrus cachexia. Citrograph 58:261-262.

35. Roistacher, C. N., Calavan, E. C., Blue, R. L., Navarro, L., and Gonzales, R. 1977. A new more sensitive citron indicator for the detection of mild isolates of citrus exocortis viroid (CEV). Plant Dis. Rep. 61:135-139.

36. Ruiz, C., Breto, M. P., and Asíns, M. J. 2000. A quick methodology to identify sexual seedlings in citrus breeding programs using SSR markers. Euphytica 112:89-94.

37. Sambrook, J., Fritsch, E. F., and Maniatis, T. 1989. Molecular Cloning: A Laboratory Manual. Cold Spring Harbor Press, Cold Spring Harbor, NY, USA.

38. Schwarz, S. F. 2001. Autotetraploides espontáneos en patrones de cítricos: Incidencia, características y comportamiento en vivero y campo. Tesis doctoral. Universidad Politécnica de Valencia.

39. Semancik, J. S., and Duran-Vila, N. 1991. The grouping of citrus viroids: Additional physical and biological determinants and relationship with disease of citrus. Pages 178-188 in: Proc Conf. Int. Organ. Citrus Virol. 11th. IOCV, Riverside, CA

40. Semancik, J. S., Gumpf, D. J., and Bash, J. A 1992. Interference between viroids inducing exocortis and cachexia disease in citrus. Ann. Appl. Biol. 121:577-583.

41. Semancik, J. S., Rakowski, A. G., Bash, J. A., and Gumpf, D. J. 1997. Application of selected viroids for dwarfing and enhancement of production of "Valencia" orange. J. Hortic. Sci. 72:563-570.

42. Semancik, J. S., and Weathers, L. G. 1972 
Exocortis virus: An infectious free-nucleic acid plant virus with unusual properties. Virology 46:456-466.

43. Serra, P., Barbosa, C. J., Daròs, J. A., Flores, R., and Duran-Vila, N. 2007. Citrus viroid V: Molecular characterization and synergistic interactions with other members of the genus Apscaviroid. Virology 370:102-112.

44. Thompson, J. D., Higgins, D. G., and Gibson, T. J. 1994. CLUSTAL W. Improving the sensitivity of progressive multiple sequences alignment through sequence weighting, positinsspecific gap penalties and weight matrix choice. Nucleic Acids Res. 22:4673-4680.

45. Vernière, C., Perrier, X., Dubois, C., Dubois,
A., Botella, L., Chabrier, C., Bové, J. M., and Duran-Vila, N. 2004. Citrus viroids: Symptom expression and effect on vegetative growth and yield of clementine trees grafted on trifoliate orange. Plant Dis. 88:1189-1197.

46. Vernière, C., Perrier, X., Dubois, C., Dubois, A., Botella, L., Chabrier, C., Bové, J. M., and Duran Vila, N. 2006. Interactions between citrus viroids affect symptom expression and field performance of Clementine trees grafted on trifoliate orange. Phytopathology 96:356368.

47. Vidalakis, G., Gumpf, D. J., Bash, J. A., and Semancik, J. S. 2004. Finger imprint of Poncirus trifoliata: A specific interaction of a vi- roid, a host, and irrigation. Plant Dis. 88:709713.

48. Visvader, J. E., and Symons, R. H. 1985 Eleven new sequence variants of citrus exocortis viroid and the correlation of sequence with pathogenicity. Nucleic Acids Res. 13:29072920.

49. Visvader, J. E., and Symons, H. 1986. Replication of in vitro constructed viroid mutants: Location of the pathogenicity modulating domain of citrus exocortis viroid. EMBO J. 5:20512055.

50. Zuker, M. 1989. On finding all suboptimal foldings of an RNA molecule. Science 244:48 52 